\title{
Similarities in Chinese Translation of The Pilgrim's Progress and that of the Bible
}

\author{
Liangxin Jiao \\ College English Teaching Dept. \\ Zaozhuang University \\ Zaozhuang, China
}

\begin{abstract}
John Bunyan's The Pilgrim's Progress from This World to That Which Is to Come (1678), one of the English classics and a Christian work, claims a book only secondary to the Holy Bible still in print. Translation has been crucial to the introduction of western knowledge and the forming of national culture in China. From the translation history of the Bible and The Pilgrim's Progress, this paper mainly focuses on three similar patterns in Chinese translation of The Pilgrim's Progress and that of the Bible.
\end{abstract}

Keywords—The Pilgrim's Progress; Bible; similar pattern; translation

\section{INTRODUCTION}

The translation of The Pilgrim's Progress and that of the Bible goes hand in hand. To some extent, the translation of The Pilgrim's Progress is in the wake of the translation of the Bible. Their text function, translation time, translation subjects, language styles, translation purpose or strategy are very similar with each other.

In this paper, the parallel progress in different patterns will be studied.

\section{A HISTORY OF CHINESE TRANSLATION OF THE BIBLE}

After transmission into China, in different stages, there were many names about the Bible such as: zhenjing, shengjing, shengshu, yizhaoshu, yizhaoshengshu, yizhaoquanshu, and Old New Testament.

Dongsheng Ren(2007:149) divided the Chinese translation of the Bible into four stages: translating-narrating phase of Nestorianist, abridged translation phase of Jesuit, complete translation phase of Protestant and diversified phase of the Chinese translation of the Bible. often:

During these four stages, translation subjects shift very

The first stage (635-845): oral paraphrasing by missionaries and recording by Chinese literates;

The second stage (from $17^{\text {th }}$ to the first half century, with intermission): the most translation done by missionaries and embellished by Chinese literates;

The third stage (from the second half century to 1919); co-operative translation by missionaries and Chinese literates;
The fourth stage (from 1920s to now): Chinese translators, Christians, Protestant Chinese and Mainland literary translators.

Just as we have mentioned above, the translation of the Bible began in 1807, while the translation of The Pilgrim's Progress began in mid-nineteenth century.

\section{THE THREE SimILAR PATTERNS IN CHINESE} TRANSLATION OF THE PILGRIM'S PROGRESS AND THAT OF THE BIBLE

\section{A. The First Similar Pattern: Shifting Pattern of Translating Subject}

The translating subjects of The Pilgrim's Progress include foreign missionaries to China (most are sinologists), Chinese literates, Chinese translators in churches and Chinese translators outside of churches. With regard to the shifting pattern of translating subject, the Chinese translation of The Pilgrim's Progress can be divided into 4 stages:

- Oral paraphrasing by missionaries and recording by Chinese literates;

- Most of the translation done by missionaries and embellished by Chinese literates;

- Missionaries and Chinese scholars translating together;

- The diversification of Chinese translation subjectivity: including Christian, Protestant Chinese and mainland literary translators.

Their translation subjects go through very similarly. At first, mainly missionaries translated the Bible, and their purposes were to propagate religion and cultivate Christians. Later on, many scholars find its literary nature. This aspect is more obvious in the translation of The Pilgrim's Progress. These years, more and more people find their beautiful languages in these two masterpieces. The Pilgrim's Progress has already been classified as "World Famous Literary Works". The Pilgrim's Progress has been used as literature course in many universities because of its literary nature. That's to say, there are double natures in text function.

The social profile of translators of The Pilgrim's Progress is more diverse in terms of extant race, class, and 
gender definitions than one might initially expect. Most of the translators were, unsurprisingly, white European men. However, ten of the thirty-seven named translators were black (nine African, one Jamaican) and six were white women.

The subjects who translated The Pilgrim's Progress varied in different times. At the very beginning, mainly foreign missionaries came to China and translated this religious work. Later on, in order to meet different readers' needs, some Chinese church scholars began to translate it. In these two stages, the mainly purpose was to propagate Christian and cultivate Protestants. With the enlargement of the number of readers, more and more people found its beautiful language. This attracted a lot of translators outside of church to translate in order to meet ordinary readers, especially non-Christians. From the acceptance of Chinese versions, Christian versions are much closer to Christians; while versions outside of church are much easier to understand by ordinary readers, especially non-Christians. Giving a comprehensive consideration of the two kinds of versions, versions with sufficient religious characteristics and also adequate notes for ordinary readers are more popular.

Not only translated The Pilgrim's Progress, Hanchuan Wang also translated The Light of Genesis and Light of life in The Tree of Life. In Doctor Hanchuan Wang's version, there were three features.

- He divided the whole book (part one) into 22 chapters and gave them separate names. This makes readers understand the contents clearly chapter by chapter.

- He gave necessary notes about the explanation of the Bible allegories, including the Bible allegories, the notes in the original and his own explanation about the text. This way of translation was not only loved by a lot of Christians but also attracted many readers outside of Christian.

- He also gave some illustrations to explain the content. In The Pilgrim's Progress published by Chinese Labor Publishing House in 2003, there are 210 illustrations. These illustrations plus adequate language make his translation more vivid.

\section{B. The second similar pattern: changes in language style}

As for their language styles, both of them go through the process of classical Chinese -Mandarin-Modern Chinese.

In 1853, William Chalmers Burns came to China. He translated The Pilgrim's Progress into classical Chinese in order to propagate tenets. Only the learned can understand it very well; while the average can only recognize the words. They cannot understand the meaning to do good things (行天 路) for others what was said in this book. Therefore, in order to meet different needs of the readers, it was translated into Mandarin so that people whether officials or the ordinary people who have the will to do good things can understand it well. With the popularity of The Pilgrim's Progress going on, it is accepted not only as a religious work, but also as a literary work. Many people are attracted by its elegant languages. Therefore, more and more modern Chinese versions come out. During that time, in order to meet some specific needs, it was even translated into many local dialects. We will enumerate this later.

From the very beginning, there have been a lot of editions of The Pilgrim's Progress, such as rewriting, abridged edition, and caricatures. It is very popular in churches as well as ordinary readers, especially nonChristians. In recent years, more and more universities use it as literary text because of its literary nature of character. Even many children read it as cartoons.

Zipeng Li (2007) mentioned that from 1851 to 2006, there are about 52 Chinese versions of this work. The first version entitled Hing kih king leih chuen was translated by Muirhead, William in 1851, in Shanghai. Then in 1853, William Chalmers Burns translated the first part of the original into classical Chinese T'een loo leih ch'ing in Xiamen. From then on, in order to satisfy different readers' needs, he translated it into different language styles in different places until 1933. In 1853, another version was published in Xiamen in local dialect. From this phenomenon, we can infer that this book was very popular in Xiamen at that time. Fujian province was a place which was very developed at that time, and a lot of missionaries assembled there disseminating religion. Only second to the Bible, The Pilgrim's Progress was also a book to spread tenets. Therefore, in order to cultivate more believers of Christian, and meet the needs of readers, translating and publishing this book were popular. From then on, there were a lot of dialect versions such as Ningbo, Shantou, Minnan, Shanghai, Hainan, Fuzhou, and Suzhou. During this time, The Pilgrim's Progress was also translated into different editions. For instance, in 1964, it was adapted into oratorio by Bennet, Rodney and translated by Ruihuai Bai in Taipei. In 1980, there was a simple extraction version version published in Hongkong. In 1985, it was adapted into radio play in Hongkong. In 1987 and 1995, The Pilgrim's Progress was published into cartoon in Taibei and Hongkong. In1994, it was translated into illustrated edition in Hongkong. In 1990s, The Pilgrim's Progress was also adapted into Chinese video tape in Taipei. In recent years, The Pilgrim's Progress was translated into modern Chinese, and also accepted as a literary work. In this thesis, we compare four different editions: New Protestant Church version, i.e. Zia, Z. K.'s version-Sheng You Ji(1936/1939); Xirong Zheng's new version (2004); Xi Hai's version (1997) and Hanchuan Wang's version (2003).

In the late $19^{\text {th }}$ century, according to the 1853 edition, there are about at least 3 versions of Chinese version of The Pilgrim's Progress: the version in Hongkong in 1856; version in Fuzhou in 1857; version in Shanghai in 1869. Besides, there are two Mandarin versions, two dialect versions-the local dialect edition of The Pilgrim's Progress.

In the local dialect edition of The Pilgrim's Progress, there are 30 illustrations with thirty subtitles. In 1853, the third year of Emperor Xianfeng's reign (咸丰, 1850-1861), the local dialect edition of The Pilgrim's Progress, begins with showing the Wicket Gate in "Fig. 1". This is the first 
subtitle in this edition. Obviously, this is not coincident with the original. The beginning of the novel is as follows:

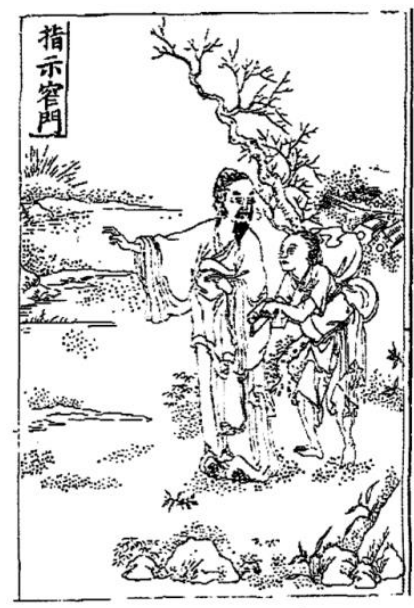

Fig. 1. Pingyuan Chen, 2003.

As I walked through the wildness of this world, I lighted on a certain place, where was a den; and I laid me down in that place to sleep: and as I slept I dreamed a dream. I dreamed...... (Bunyan, 1984:39)

This kind of expression is like the illustrated fiction. Illustrators of The Pilgrim's Progress read this book as a classical novel, and made a series of pictures according to the tradition of illustrated fiction where the pictures themselves have independence, rather than just illustrate some classical situations.

The crucifixion of Jesus in "Fig. 2" is an event described in all four gospels which takes place immediately after his arrest and trial.

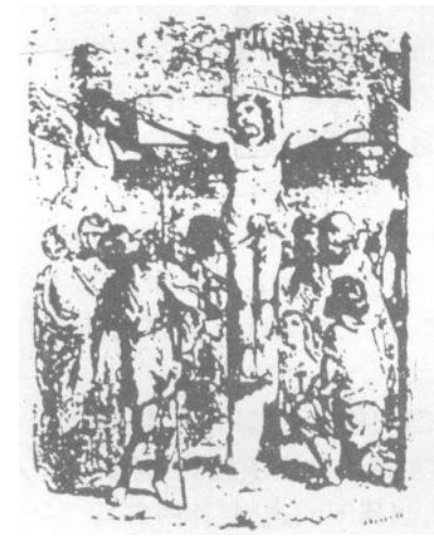

Fig. 2. The Crucifixion, 1622 (Pingyuan Chen, 2003).

From "Fig. 1" and "Fig. 2", readers can distinctly editors' respect to pictures. All in all, inserting illustrations is a feature of magazines in the late Qing Dynasty (1644-1912).

The reason why The Pilgrim's Progress was retranslated into dialect was to be accepted by readers in Guangzhou easily. The Pilgrim's Progress was an English novel which was first introduced into China. In 1850s, The Pilgrim's
Progress had already landed in China. The problem was that it was basically published and read by churches. People didn't read it as a novel.

This situation of neglecting literary values lasted for a long time - although there are a lot of bosom friends. For example, Zuoren Zhou noticed the literary value very early. He gave his excellent evaluation in European Literature (Zuoren Zhou, 1989) which was firstly published in 1919:

[Bunyan] wrote The Pilgrim's Progress in allegorical way in prison which is divine. His book is vigorous, concise, and elegant in spirit. It not only propagates doctrines, but also became the authority of contemporary novels. Although his style is the same as Faerie Queen's style, the dream narrated in the novel describes the real world, which is nearly a novel. (Tr. by the author)

After 1920s, in the course of European Literature, The Pilgrim's Progress got a lot of praise, but the ordinary readers still didn't recognize its literary value. An obvious example was that in the early $20^{\text {th }}$ century, lots of "The World Famous Masterpieces" were introduced into China except The Pilgrim's Progress. In the late 1930s, eventually there was Zia, Z. K.'s version which was published by Christian Literature Society. That's to say, it was still accepted as religious reading. Zia, Z. K.'s version was republished in Hongkong and other cities which had great influence. However, in recent 30 years, great changes have taken place. There are about 20 kinds of new versions about The Pilgrim's Progress, including rewriting versions and pictorial drawings. What's more, they were introduced and translated as literary masterpieces. Nowadays, there are a lot of translation novels in the late Qing Dynasty (1644-1912), and The Pilgrim's Progress was accepted by more and more ordinary readers. Therefore, not only its religious nature but its literary value needs learning by us. (Pingyuan Chen, 2003)

\section{The Third Similar Pattern: Variations in Translation Functions}

Different text styles have different text functions, and different texts are supposed to adopt different translation strategies. In literary translation, the translator can regulate his version to the original context time and rhythm on condition that functions are equivalent. That's to say, the translator must have semantic consciousness as well as function consciousness in order to make the original and his version equivalent in meaning and function. Only in this way, can a translator produce correct and fluent versions which are equivalent to the original. As for the text function, it has a very close relationship with text nature of character. The Pilgrim's Progress as a religious text, disseminating tenets is the first function of this work. While, except for religious nature, it is also a literary work. From its language, to appreciate its literary is also very important. That's to say, because of its double nature of character, the text function also have double nature of character.

In this paper, I divide readers of The Pilgrim's Progress into two groups: Christian readers and Non-Christian readers. The first group of readers expects that language in this book is normal. 
Andrew Chesterman (1993) called the collective expectation readers in group for version expectancy norms. He thought that these norms were built by readers' expectation of a kind of work to these works. On one hand these expectations came from the popular translation norms in the cultural system of source language; on the other hand, they can be dated back to the economic situation, ideology, power distribution, etc. Gideon Toury (1980) put forward the definition of "norm" from the view of descriptive translation study. He thought that norm was the value or ideology held by members in a society which they considered right or wrong, appropriate or not. They transformed it and then formed specific direction. These directions can be fit for and applied to especial situation, while they have not developed into definite laws.

The second group of readers often expects that the language in the book should have few religious words, but more exoteric language, so that it is easy to understand by non-Christians. That requests that the translator should consider their own readers while translating. We have already compared different versions of different translators in the paper above.

"One hundred readers, one hundred Hamlets." This is a very famous sentence in literature. As for the same work, different readers, more often than not, have different responses. Meanwhile, readers' response is very important to the authors or translators. It decides the popularity and delivery of the book. To some extent, it decides how the translator translates a literary work.

As for the readers, because of their different cultural status, their understanding is also different. Too professional the ordinary people cannot understand it. Too easy, more often than not, cannot express the original. To consider both the author and different readers is not a very easy job.

\section{CONCLUSION}

This paper studies the patterns in Chinese translation of The Pilgrim's Progress and that of the Bible. According to the content above, the Chinese translation of The Pilgrim's Progress is similar.

\section{REFERENCES}

[1] Andrew Chesterman. Translation as theory. Finland: Kaantaj.1993(3).

[2] Bunyan, John. The Pilgrim's Progress, from This World to That Which Is to Come. Aylesbury, Bucks: Hazell Watson \& Viney Limited: Penguin Books Ltd.,1984.

[3] Pingyuan Chen. Drawing narration of church books in late Qing dynasty. academic research, 2003(11): 112-116.

[4] Hofmeyr, Isabel. The Portable Bunyan-A Translation History of The Pilgrim's Progress. New Jersey: Princeton University Press, 2004.

[5] Dongsheng Ren. Study on the tradition of Bible translation into Chinese. Wuhan: Hubei Education Press, 2007, pp.149.

[6] Gideon Toury. A Rational for Descriptive Translation Studies. The Art and Science of Translation. Dispositio 7,1980.

[7] Zipeng Li. Study on Chinese version of The Pilgrim's Progress.Foreign Language and Translation, 2007. pp. 26-40.

[8] Hanchuan Wang. Bunyan, John. The Pilgrim's Progress .Beijing: Workers' Press, 2003.
[9] Xi Hai. Bunyan, John. The Pilgrim's Progress. Shanghai: Shanghai Translation Publishing House, 1997.

[10] Xirong Zheng. Bunyan, John. The Pilgrim's Progress. Shanghai: China Christianize Patriotic Movement Committee, China Christian Council, 2004.

[11] Zia, Z. K. Bunyan, John. The Pilgrim's Progress. Shanghai: The Christian Literature Society for China, 1936/1939.

[12] Zuoren Zhou. European Literature. Changsha:Yuelu Press, 1989. 